\title{
Efficacy and safety of multidrug therapy in paucibacillary leprosy in Singapore
}

\author{
JOYCE TENG-EE LIM* \& TULIP TAN \\ 1 Mandaly Road, National Skin Centre, Singapore 1130
}

Accepted for publication 6 November 1992

\begin{abstract}
Summary A total of 49 patients with paucibacillary leprosy (PB) who completed multidrug therapy (MDT) between 1985 and 1990 were analysed retrospectively for efficacy and complications; $20(40 \cdot 8 \%)$ patients had borderline-tuberculoid (BT), $13(26 \cdot 5 \%)$ had tuberculoid (TT), 1 (2.1\%) had indeterminate (I) and 15 $(30.0 \%)$ had pure neural $(\mathrm{N})$ leprosy; 26 patients $(76.5 \%$ of 34 non-neural leprosy) were skin biopsied for histological cure before MDT was stopped. Of these 26 patients, 19 had histological clearance at 6 months while the remaining 7 cleared beyond 1 year (18-36 months). The remaining 8 non-neural patients who ref used rebiopsy had MDT for 6-8 months and the MDT was stopped when there was clinical clearance. Of the 15 neural $(\mathrm{N})$ leprosy patients, 11 were given MDT for 6 months while the rest had 12-18 months of treatment; 1 patient with neural leprosy, who was treated for 6 months, relapsed with BT leprosy 18 months posttreatment.

There were few complications among the 49 patients- $-4(8.2 \%)$ patients developed reaction to dapsone, $1(2 \cdot 0 \%)$ had the dapsone syndrome, $2(4 \cdot 1 \%)$ had haemolytic anaemia and $1(2 \cdot 0 \%)$ had dapsone hepatitis; $7(14 \cdot 3 \%)$ patients had type I reaction.
\end{abstract}

\section{Introduction}

Multidrug therapy (MDT) treatment, as recommended by WHO for paucibacillary (PB) leprosy, ${ }^{1}$ has been in existence since 1982. Although efficacious there are now reports of relapses with this treatment. ${ }^{2-5}$ In Singapore, leprosy patients are being treated in only a single government dermatology centre, the National Skin Centre, Singapore (formerly the Middle Road Hospital). We had 49 PB patients who completed MDT between June 1985 and May 1990. The aim of this paper is to evaluate the efficacy and safety of MDT among our PB leprosy patients.

* Correspondence

0305-7518/93/064136+07\$01.00 Lepra 


\section{Materials and methods}

A total of 49 PB patients (according to the Ridley-Jopling classification) who completed MDT between June 1985 and May 1990 were analysed retrospectively for efficacy and complications. MDT consisted of rifampicin ( $600 \mathrm{mg}$ monthly, taken under supervision), and dapsone (100 mg daily). Our treatment regime differed from the standard WHO recommendations in that MDT was not arbitarily terminated at 6 months but continued with regular assessment until histological or clinical cure, or both, were achieved.

Only newly-diagnosed PB patients who completed MDT were included in the study. All non-neural PB leprosy patients had both clinical and histological diagnosis of leprosy, and 4 of our neural $(\mathrm{N})$ leprosy patients had histological diagnosis while in the remaining 11 the diagnosis was made on clinical grounds. All patients were clinically assessed initially at 3 weeks for Lepromin Test reading and subsequently at monthly intervals. Baseline investigations included slit skin smears for acid-fast bacilli (AFB), lepromin test, Glucose 6-phosphatase deficiency (G6PD) screen, blood counts and liver function tests. At monthly follow-up visits the urine was checked for the presence of dapsone, and blood for haemoglobin and reticulocyte count. Liver function tests were done where indicated.

We considered failed MDT if the patients continued to develop new lesions, had a worsening of existing lesions, or developed new neurological deficits while on treatment. There should also have been an increase in histological activity. If the patients had some improvements while on MDT, they were not considered to be treatment failures. These patients were not considered to have late reversal reactions as they had no initial improvement while on treatment. Patients who failed $M D T$ were treated with rifampicin $600 \mathrm{mg}$ and clofazimine $300 \mathrm{mg}$ under supervision monthly; and clofazimine $100 \mathrm{mg} 3$ times a week with ethoionamide $375 \mathrm{mg}$ per day, unsupervised.

Clinical cure for neural patients with grade 2 or 3 deformities (WHO definition) was defined arbitrarily when patients had recovery of sensory but not motor deficits.

As far as possible, post-treatment biopsy of the same site as at diagnosis was done af ter 6 months' treatment. If histological activity persists at 6 months rebiopsies should be repeated every 6 months or before MDT was stopped. After MDT was stopped all patients were followed up at 6-12 monthly intervals for clinical relapse. Clinical relapse was defined as the emergence of new skin lesions with or without the increase in redness, thickness and diameter of existing skin lesions or new muscle paralysis. A histological diagnosis is needed to confirm clinical relapse. Patients are released from surveillance after being disease-free for 5 years.

\section{Results}

We had $20(40 \cdot 8 \%)$ patients with borderline-tuberculoid (BT), $13(26 \cdot 5 \%)$ with tuberculoid (TT), $1(2 \cdot 1 \%)$ with indeterminate (I) and $15(30 \cdot 6 \%)$ with neural (N) leprosy. There were 31 male patients and 18 female patients giving a male to female ratio of $1 \cdot 7: 1$. The age of onset ranged from 19 to 87 years. There were 37 Chinese (75.5\%), 8 Malays $(16 \cdot 3 \%)$ and 4 Indians $(8 \cdot 2 \%)$ in the study, which reflected the racial composition in Singapore.

In all, $38(77 \cdot 6 \%)$ patients had 6 months of MDT while the remaining $11(24 \cdot 5 \%)$ had 
Table 1. Results of treatment

\begin{tabular}{|c|c|c|c|c|c|c|c|}
\hline \multirow{2}{*}{$\begin{array}{l}\text { Treatment } \\
\text { duration } \\
\text { (months) }\end{array}$} & \multirow[b]{2}{*}{ Type of cure } & \multicolumn{4}{|c|}{ No. of patients } & \multirow[b]{2}{*}{ Sıbbtotal } & \multirow[b]{2}{*}{ Total $(\%)$} \\
\hline & & BT & TT & I & $\mathbf{N}$ & & \\
\hline \multirow[t]{2}{*}{6} & Clinical cure & 2 & 5 & 1 & $11 *$ & 19 & \multirow{2}{*}{$38(77 \cdot 6)$} \\
\hline & Clinical and histological cure & 12 & 7 & - & - & 19 & \\
\hline \multirow[t]{2}{*}{12} & Clinical cure & - & - & - & 3 & 3 & \multirow{2}{*}{$3(6 \cdot 1)$} \\
\hline & Clinical and histological cure & - & - & - & - & 0 & \\
\hline \multirow[t]{2}{*}{18} & Clinical cure & - & - & - & 1 & 1 & \multirow{2}{*}{$3(6 \cdot 1)$} \\
\hline & Clinical and histological cure & 1 & $1 \dagger$ & - & - & 2 & \\
\hline \multirow[t]{2}{*}{24} & Clinical cure & - & - & - & - & 0 & \multirow{2}{*}{$3(6 \cdot 1)$} \\
\hline & Clinical and histological cure & $3 \dagger$ & - & - & - & 3 & \\
\hline \multirow[t]{2}{*}{30} & Clinical cure & - & - & - & - & 0 & \multirow{2}{*}{$2(4 \cdot 1)$} \\
\hline & Clinical and histological cure & $2 \ddagger$ & - & - & - & 2 & \\
\hline Total & & 20 & 13 & 1 & 15 & 49 & $49(100)$ \\
\hline
\end{tabular}

* Signifies that: 1 patient (biopsied proven, positive AFB) developed BT within 2 years; $\uparrow 1$ patient in each group had clinical and histological activity at 12 monthstherapy change to rifampicin and clofazimine (failed MDT treatment); $\ddagger 1$ patient had dapsone induced hepatitis within 6 months - clofazimine replaced dapsone; 1 patient had rifampicin and clofazimine (failed MDT treatment).

MDT from 12 to 30 months (Table 1). Of the 38 patients who had 6 months of treatment, 19 had a clinical" and histological cure while the remaining 19 had clinical inactivity. Among the patients who received MDT for longer than 6 months, 4 were neural $(\mathrm{N}), 6$ were BT and 1 was TT leprosy. Of these patients 3 were considered to have failed MDT treatment after 6 or 12 months and given rifampicin and clofazimine instead, 2 patients had BT and 1 patient had leprosy (Table 1).

The BT leprosy patients tend to achieve histological clearance at a later date-of the 20 patients 6 cleared after 18-30 months' treatment. Only 1 of the 13 TT leprosy patient required treatment after 6 months. This patient had activity at 12 months which cleared after he was given rifampicin and clofazimine for 6 months; 11 of the 15 neural patients had MDT for 6 months while the remaining 4 had 12-18 months of MDT. However, 1 neural patient with Grade 1 deformity (sural nerve biopsied proven and acid fast bacilli positive) who had 6 months of MDT, relapsed with BT leprosy 18 months later. He had had no previous skin lesions but now presented with new skin lesions. He was re-treated with rifampicin and clofazimine.

The complications of treatment are summarized in Table 2 . Only $4(8.2 \%)$ patients had drug reactions - $1(2 \cdot 0 \%)$ had dapsone syndrome, $1(2 \cdot 0 \%)$ had dapsone hepatitis and $2(4 \cdot 1 \%)$ had haemolytic anaemia (both are G6PD positive); $7(14 \cdot 3 \%)$ patients, all of whom had BT leprosy, developed Type I reactions. 
Table 2. Treatment complications

\begin{tabular}{|c|c|c|}
\hline Complications & Type & No. of patients \\
\hline Drug reactions & $\begin{array}{l}\text { Dapsone syndrome } \\
\text { Haemolytic anaemia } \\
\text { Dapsone hepatitis }\end{array}$ & $\begin{array}{ll}1 & (2 \cdot 0) \\
2 & (4 \cdot 1) \\
1 & (2 \cdot 0)\end{array}$ \\
\hline Type I reactions & $\begin{array}{l}\text { Erythema/Oedema of existing lesions } \\
\text { Nerve pain/tenderness }\end{array}$ & $\begin{array}{rr}5 & (10 \cdot 2) \\
2 & (4 \cdot 1)\end{array}$ \\
\hline Total & & $11(22 \cdot 4)$ \\
\hline
\end{tabular}

\section{Discussion}

The efficacy of MDT has been generally accepted. Some authors ${ }^{4,6}$ accepted it with some reservation mainly with regard to the duration of therapy. In Singapore, leprosy is being treated only in a single government centre and here clinical and histological assessment could be done before stopping therapy. We do not stop treatment abruptly at 6 months if there is evidence of clinical or histological activity.

After 6 months of MDT we had a cure rate of $77 \cdot 6 \%$ (38 patients) while $22 \cdot 4 \%$ (11 patients) had either clinical or histological activity. Other authors ${ }^{2-4,7}$ also have had similar experiences with the persistence of disease at the end of 6 months of MDT, ranging from $6.5 \%$ to more than $30 \%$. However, our cure rates improved when MDT was continued after 6 months, with cure rates of $83.7 \%$ at 12 months, $89 \cdot 8 \%$ at 18 months, $95 \cdot 9 \%$ at 24 months and $100 \%$ at 30 months (Table 1). Other field studies ${ }^{2,3,7}$ continued with dapsone monotherapy or MDT after 6 months until clinical cure. They too, showed a further increase in cure rates ranging from $6 \cdot 5 \%$ to $57 \%$ (Table 3), suggesting that 6 months of MDT might not be adequate.

Of the patients who required more than 6 months of treatment, 6 had BT, 1 had TT, 1 had indeterminate and 4 had neural leprosy. The 6 BT patients had treatment beyond 18 months, 2 of whom required failed MDT treatment and 1 had clofazimine instead of dapsone (as he had dapsone induced hepatitis). Repeated biopsies at 6-monthly intervals from these BT patients showed histological activity beyond 12 months. This suggested that some BT patients required a longer duration of treatment.

Table 3. Clinical cure rates compared with other studies

\begin{tabular}{|c|c|c|c|}
\hline Study & $\begin{array}{c}\text { No of } \\
\text { patients }\end{array}$ & $\begin{array}{l}\text { Cure rates } \\
\text { at } 6 \text { months } \\
(\%)\end{array}$ & $\begin{array}{c}\text { Additional cure rates } \\
\text { at } 12 \text { months } \\
(\%)\end{array}$ \\
\hline J. Lim et al. (1990) & 49 & $77 \cdot 6$ & $+6 \cdot 1^{*}$ \\
\hline Chopra et al. $(1990)^{2}$ & 10,995 & $93 \cdot 5$ & $+6 \cdot 5^{*}$ \\
\hline Katoch et al. (1989) & 88 & 66 & $+28 \dagger$ \\
\hline Grugni et al. $(1988)^{14}$ & 736 & 44 & $+25^{*}$ \\
\hline
\end{tabular}

* Continued with WHO MDT.

$\uparrow$ Continued with Dapsone monotherapy. 
Revankar ${ }^{8}$ found disease activity among $17 \%$ of his BT patients 3 years after MDT. He also suggested that BT leprosy should be treated longer. Studies ${ }^{3,9,10}$ have also shown that BT leprosy patients have a higher rate of relapse compared to other groups. However, no relapse was observed among our BT patients, probably because of our extended treatment period.

In total, 11 of our 15 neural patients had only 6 months of MDT. These patients had recovery of sensory deficits. However, 1 of these patients developed BT within 2 years (sural nerve biopsy showed AFB). He was re-treated with rifampicin and clofazimine. Whether neural patients, especially those with positive AFB, should be treated beyond 6 months is still uncertain.

It could be argued that patients who still had clinical or histological activity at 6 months might continue to improve even if MDT was then stopped. As this is a retrospective study with no such control groups, there is no way of knowing this. However, it seemed unlikely as 10 of these patients had neural or BT leprosy. It had been suggested that both these groups of patients require longer periods of treatment to prevent relapse. ${ }^{8}$ Besides, we and others, ${ }^{2-4,7}$ had shown that disease activity persisted beyond 6 months of MDT.

Our relapse rate is low (2\%) compared to others (Table 4). This might be due to the fact that treatment was individualized and extended where necessary. We followed up 34 patients $(69 \cdot 4 \%)$ for at least 2 years post-treatment.

MDT appeared safe as only $4(8 \cdot 2 \%)$ of our patients developed reactions to dapsone. No reaction to rifampicin or clofazimine was reported. The 2 patients who developed dapsone-induced haemolytic anaemia were G6PD positive and haemolysis was doserelated. No haemolysis recurred when dapsone was reduced to $50 \mathrm{mg}$ daily. Hypersensitivity reaction to dapsone occurs in less than $0.5 \%$ of those taking the drugs, and usually begins 1-4 weeks after administration of the drug. ${ }^{11}$

The full dapsone syndrome was developed by 1 of our patients. ${ }^{12}$ Another patient had hepatocellular damage after a latent period, which could be either a hepatoxic effect or even be a partial dapsone syndrome. ${ }^{13}$ However, both recovered fully on stopping dapsone.

Table 4. Relapse rates compared with other studies

\begin{tabular}{lccc}
\hline & & \multicolumn{2}{c}{ Relapse } \\
\cline { 3 - 4 } Study & $\begin{array}{c}\text { No. of } \\
\text { patients }\end{array}$ & No. of patients & Rate \\
\hline J. Lim et al. $(1990)$ & 49 & 1 & $(2)$ \\
Chopra et al $(1990)^{2}$ & 10,995 & 21 & $(0 \cdot 19)$ \\
Grugni et al. $(1990)^{3}$ & 1,509 & 85 & $(5 \cdot 63)$ \\
Pavithran $(1988)^{4}$ & 25 & 3 & $(12)$ \\
Reddy et al. $(1988)^{5}$ & 92 & 4 & $(8 \cdot 4)$ \\
Katoch et al. $(1989)^{7}$ & 70 (MDT) & 9 & $(12 \cdot 9)$ \\
& 84 (modified MDT) & 1 & $(1 \cdot 2)$ \\
Rangarai et al. $(1986)^{9}$ & 237 & 14 & $(5 \cdot 9)$ \\
Van Brakel et al. $(1989)^{10}$ & 555 & 16 & $(2 \cdot 9)$ \\
& & & \\
\hline
\end{tabular}




\section{Conclusion}

We concluded from our data that short-term WHO MDT is effective and safe. We have a cure rate of $77 \cdot 6 \%$ at 6 months of MDT, a low relapse rate of $2 \%$ and a complication rate of $8 \cdot 2 \%$ (from dapsone). We agree with others ${ }^{3,14}$ that the duration of MDT should be tailored to the individual. It should not be arbitrarily stopped at 6 months, and extended periods of treatment may be necessary, especially in some cases of BT leprosy.

\section{References}

1 WHO Study Group. Chemotherapy of leprosy for control programme. Technical Report Series No. 657. WHO: Geneva, 1982.

2 Chopra NK, Agarawal JS, Pandya PG. A study of relapse in paucibacillary leprosy in a multidrug therapy project, Baroda District, India. Lepr Rev, 1990; 61: 157-62.

${ }^{3}$ Grugni A, Nadkarni NS, Kini MS, Mehta VR. Relapses in paucibacillary leprosy after MDT-a clinical study. Int J Lepr Other Mycobact Dis, 1990; 58: 19-24.

${ }^{4}$ Pavithran K. Relapse of paucibacillary leprosy after a short-course of multidrug therapy. Ind J Lepr, 1988; 60: $225-9$.

5 Reddy PK, Mohinuddin SK. Pattern of relapses in paucibacillary leprosy patients treated with MDT (WHO 1982). Ind. J Lepr, 1988; 60: 581-8.

${ }^{6}$ Dharmendra Correspondence-Editorial Comment. Ind J Lepr, 1985; 57: 227.

${ }^{7}$ Katoch K, Ramanathan U, Natrajan M, Bagga AK, Bhatia AS, Saxena RK, Ramu G. Relapses in paucibacillary leprosy patients after treatment with three short-term regimens containing Rifampicin. Int $J$ Lepr Other Mycobact Dis, 1989; 57: 458-64.

8 Revankar CR, Karjivkar VG, Gurav VJ, Ganapati R. Clinical assessment of paucibacillary leprosy under multidrug therapy - three years follow up study. Ind J Lepr, 1989; 61: 355-8.

9 Rangaraj M, Rangaraj J. Experience with multidrug therapy in Sierra Leone. Clinical, operational and managerial analysis. Lepr Rev, Suppl 3, 1986; 57: 77-91.

10 Van Brakel W, Kist P, Nable S, O'Tovle S. Relapses af ter multidrug therapy for leprosy: a preliminary report of 22 cases in West Nepal. Lepr Rev, 1989; 60: 45-50.

11 Sherlock S. Prediction of hepatotoxicity due to therapeutic agents in man. Medicine, 1966; 45: 453-8.

12 Kromann NP, Vilhelmsen R, Stahl D. The Dapsone Syndrome. Arch Dermatol, 1982; 118: 531-2.

13 Johnson DA, Cattau EL, Kuritzky JN, Zimmerman HJ. Liver involvement in the sulfone syndrome. Arch Intern Med, 1986; 146: 875-7.

14 Grugni A, Nadkarni NJ. Kini MS. Multidrug therapy in paucibacillary leprosy-a fiveyear experience. Ind $J$ Lepr, 1988; 60: 589-92. 


\title{
Éfficacité et sureté de la thérapeutique multidrogue dans la lèpre paucibacillaire à Singapour
}

\author{
Joyce Teng-Ee Lim et Tulip Tan
}

Résumé Quarante neuf patients atteints de lèpre paucibacillaire (PB), qui avaient suivi jusqu'à complétion un traitement multidrogue (MDT) entre 1985 et 1990 ont été examinés rétrospectivement pour rechercher l'efficacité et les complications. La lèpre était borderline tuberculoïde (BT) chez vingt patients, tuberculö̈de(TT) chez treize patients $(26,5 \%)$, indéterminée (I) chez un patient $(2,1)$ tandis que quinze patients $(30,0 \%)$ présentaient une lèpre névritique pure. Vingt-six patients (76,5\% des 34 lèpres non névritiques) ont subi une biopsie cutanée pour rechercher la guérison histologique avant l'arrêt du traitement multidrogue. Sur ces vingtsix patients, dix-neuf ont obtenu la clearance histologique à 6 mois tandis que les autres 7 mettaient plus d'un an à l'atteindre (18 à 36 mois). Les huit derniers patients non névritiques qui ont ref usé la seconde biopsie ont reçu MDT pendant 6 à 8 mois et le MDT a été arrété à la clearance clinique. Sur les quinze patients atteints de lèpre névritiique $(\mathrm{N})$, onze ont reçu MDT pendant 6 mois tandis que le reste avait 12 à 18 mois de traitement. Un patient atteint de lèpre névritique, traité pendant 6 mois, a rechuté avec une lèpre BT 18 mois après l'arrêt du traitement.

Il y a eu quelques complications chez les 49 patients. Quatre patients $(8,2 \%)$ ont présenté une réaction à la dapsone, un $(2,0 \%)$ a eu le syndrome dapsone, deux $(4,1 \%)$ ont eu une anémie hémolytique et un $(2,0 \%)$ a eu une hépatite dûe à la dapsone. Sept patients $(14,3 \%)$ ont eu une réaction de type $\mathrm{I}$.

\section{Efficacia y seguridad de la terapia multidroga en la lepra paucibacilar, en Singapúr}

\author{
Joyce Teng-Ee Lim y Tulip Tan
}

Resumen Se analizaron retrospectivamente cuarenta y nueve pacientes sufriendo de lepra paucibacilar (PB) que habían completado terapia multidroga (MDT) durante los años 1985 a 1990, para eficacia y complicaciones. Veinte pacientes $(40,8 \%)$ tenían Lepra Tuberculoide Dudosa (BT), trece $(26,5 \%)$ Tuberculoide (TT), uno $(2,1 \%)$ tenía Indeterminada (I) y $15(30,0 \%)$ Neural pura $(\mathrm{N})$. Veinte y seis pacientes $(76,5 \%$ de los 34 con lepra no neural) fueron examinados por biopsia de la piel para una cura histológica antes de descontinuar el MDT. De estos veinte y seis pacientes, diez y nueve pasaron el examen histológico después de 6 meses, y los demás pasaron después de 1 año ( 18 a 36 meses). Los restantes 8 pacientes no neurales que rehusaron la biopsia recibieron MDT por 6 a 8 meses, descontinuando después de pasar el examen clínico. De los quince pacientes con lepra neural (N), 11 recibieron MDT por 6 meses, y los demás fueron tratados por 12 a 18 meses. Un paciente con lepra neural que fue tratado por 6 meses, tuvo una recaída de lepra BT 18 meses después del tratamiento.

Hubieron pocas complicaciones entre los cuarenta y nueve pacientes. Cuatro $(8,2 \%)$ desarrollaron una reacción contra la dapsona, uno $(2,0 \%)$ tuvo el síndrome de la dapsona, dos $(4,1 \%)$ tuvieron anemia hemolítica y uno $(2,0 \%)$ hepatitis debido a la dapsona. Siete $(14,3 \%)$ de los pacientes tuvieron una reacción de Tipo 1 . 